\title{
Morphological characteristics of a series of alien monosomic addition lines of Japanese bunching onion (Allium fistulosum L.) with extra chromosomes from shallot $(A$. cepa $\mathrm{L}$. Aggregatum group)
}

\author{
Masayoshi Shigyo*, Mitsuyasu Iino, Shiro Isshiki, and Yosuke Tashiro \\ Department of Biotechnology and Plant Breeding, Faculty of Agriculture, \\ Saga University, Saga 840, Japan
}

(Received 9 June 1997, accepted 18 July 1997)

\begin{abstract}
To study the effect of the extra chromosomes on morphological characters both in vegetative and reproductive stages, a series of alien monosomic addition lines of Japanese bunching onion (Allium fistulosum L.) with extra chromosomes from shallot (A. серa L. Aggregatum group) were grown in the experimental farm of Saga University, Saga, Japan. Several morphological characters of the alien monosomic addition lines were found to be specific for the respective alien chromosomes from $A$. cepa Aggregatum group. The most distinctive characteristics in each alien monosomic addition line were as follows; spheroidal spathe in $\mathrm{FF}+1 \mathrm{~A}$, bloom-less leaf blade in $\mathrm{FF}+2 \mathrm{~A}$, slow expansion of leaf in $\mathrm{FF}+3 \mathrm{~A}$, acuminate spathe in $\mathrm{FF}+4 \mathrm{~A}$, reddishyellow leaf sheath in $\mathrm{FF}+5 \mathrm{~A}$, arch-like leaf brade in $\mathrm{FF}+6 \mathrm{~A}$, fast expansion of leaf in $\mathrm{FF}+7 \mathrm{~A}$, and intensely yellow anther in $\mathrm{FF}+8 \mathrm{~A}$. The results indicate that these character expressions are deeply related to alien genes on extra chromosomes from $A$. cepa Aggregatum group.
\end{abstract}

\section{INTRODUCTION}

A series of alien monosomic addition lines (AMALs) of $A$. fistulosum with the extra chromosomes from A. cepa Aggregatum group ( $\mathrm{FF}+1 \mathrm{~A}$ to $\mathrm{FF}+8 \mathrm{~A})$ was established in our previous study (Shigyo et al., 1996). Chromosomal locations of isozyme and 5S rRNA genes in A. cepa Aggregatum group had been determined using the series (Shigyo et al., 1994; Shigyo et al., 1995a; Shigyo et al., 1995b; Shigyo et al., 1996). The series seems to be a material useful also for determination of the chromosomal locations of the genes controlling morphological characters in A. cepa Aggregatum group. In the AMALs of sugar beet (Beta vulgaris L.) and rice (Oryza sativa L.), it was revealed that extra chromosomes from wild species had various effects on the morphological characters of the recipient species (Lange et al., 1988; Jena and Khush, 1989; Reamon-Ramos and Wricke, 1992; Yasui, 1997).

In the present study, morphological characters of shoot, leaf, and flower organs were examined to evaluate the effects of extra chromosomes from A. cepa Aggregatum group on the character expressions in A. fistulosum. Furthermore, chromosomal locations of the genes controlling some

\footnotetext{
* Corresponding author.
}

of these characters were discussed.

\section{MATERIALS AND METHODS}

Plant materials consisted of the 37 AMALs were produced in our previous study (Shigyo et al., 1996). A. fistulosum cv. 'Kujyo' which had been used in raising the AMALs was also examined as control. From March, 1995 to February, 1996, the plants were grown in the experimental farm of Saga University (N33 ${ }^{\circ} 14^{\prime}$, E $\left.130^{\circ} 17^{\prime}\right)$, Saga, Japan. A compound fertilizer was applied before planting. Total amounts of three major nutrients in a basal dressing were $100 \mathrm{~N}$ (as ammonium sulfate), $120 \mathrm{P}$ (as calcium superphosphate), and $100 \mathrm{~K}$ (as potassium chloride) $\mathrm{kg} / \mathrm{ha}$. The width of the ridge for each plant was $25 \mathrm{~cm}$, and the intrarow spacing was $30 \mathrm{~cm}$. A silver mulching was further applied. The organs and characters examined in this study are summarized in Table 1 . The times and methods of the examinations are also shown in Table 1.

\section{RESULTS AND DISCUSSION}

For most of the characters examined, the data showed considerable variations both within and among the AMALs (Figs. 1 and 2). Though all the plants of A. fistulosum had 
Table 1. Characters investigated in this study

\begin{tabular}{ll}
\hline \hline \multicolumn{1}{c}{ Organ } & \multicolumn{1}{c}{ Character } \\
\hline Whole plant & Survival rate (12 months after planting) \\
Shoot & Number of tillers (6 months after planting) \\
Leaf & Leaf sheath length (6 months after planting) \\
& Leaf blade length (6 months after planting) \\
& Leaf sheath diameter (6 months after planting) \\
& Leaf sheath color (+; reddish-yellow, -; white) \\
& Leaf blade color (Scale 1-5 from light green to deep green) \\
& Number of expanding leaves per tiller (every month from Aug., 95' to Feb., 96') \\
& Spathe shape \\
& Flower stalk length (just after blooming) \\
& Number of florets (one inflorescence) \\
& Pedicel length (just after blooming) \\
& Outer filament length \\
& Inner filament length \\
& Anther length \\
& Anther width \\
& Anther color (Scale 1-7 from light yellow to deep yellow) \\
& Ovary color (Scale 1-7 from light green to deep green) \\
\hline
\end{tabular}

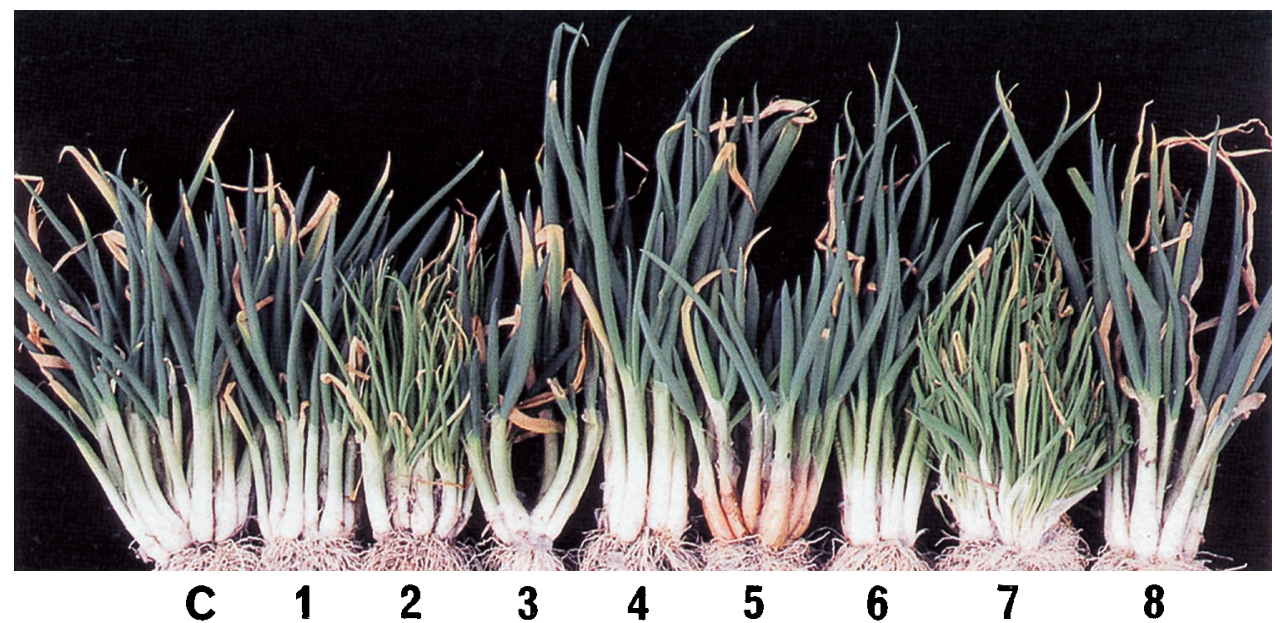

Fig. 1. Plants of a series of alien monosomic addition lines (1-8) and A. fistulosum (C) in vegetative stage. Each arabic numeral (1-8) corresponds to the extra chromosomes (1A to $8 \mathrm{~A}$ ) of the alien monosomic addition lines. $\times c a .1 / 12$.

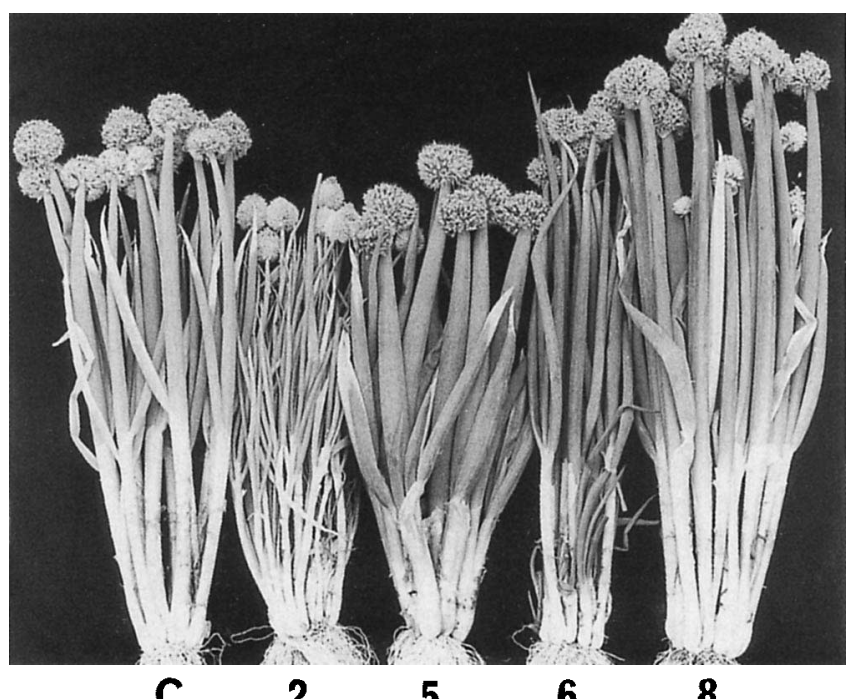

C 2
5

Fig. 2. Plants of alien monosomic addition lines (2, 5, 6, and 8) and $A$. fistulosum $(\mathrm{C})$ in reproductive stage. Each arabic numeral $(2,5,6$, and 8$)$ corresponds to the extra chromosomes $(2 \mathrm{~A}, 5 \mathrm{~A}, 6 \mathrm{~A}$, and $8 \mathrm{~A})$ of the alien monosomic addition lines. $\times c a .1 / 14$. 
survived during the term of the investigation, some plants had withered or died in all types of the AMALs (Table 2). The survival rates of the AMALs FF+1A and FF+3A were low. It seems that these two types of the AMALs have low tolerance to high temperature and humidity in summer.

The numbers of tillers in all types of AMALs except $\mathrm{FF}+8 \mathrm{~A}$ were fewer than that in A. fistulosum. Few numbers of tillers were observed in $\mathrm{FF}+1 \mathrm{~A}, \mathrm{FF}+4 \mathrm{~A}$, and $\mathrm{FF}+6 \mathrm{~A}$. A rapid formation and elongation of axillary buds from late autumn to early winter was observed in FF+2A and FF+7A. However, the numbers of tillers were not large in the two types of the AMALs since the elongated axillary buds had been eternally covered with old leaf sheaths and had not been counted as tillers. Plants of $\mathrm{FF}+4 \mathrm{~A}$ grew vigorously and was the largest in all the AMALs judging from the leaf length and leaf sheath diameter. Plants of FF+2A, FF+3A, and $\mathrm{FF}+5 \mathrm{~A}$ were small. Reddish-yellow leaf sheaths were observed only in FF+5A. The color of leaf blade in FF+2A and $\mathrm{FF}+7 \mathrm{~A}$ was light green, and those of other AMALs and A. fistulosum were deep green. Further, FF+2A had bloomless leaves.

The fast expansion of leaf was observed in $\mathrm{FF}+1 \mathrm{~A}$, $\mathrm{FF}+2 \mathrm{~A}$, and $\mathrm{FF}+7 \mathrm{~A}$, and the slow expansion of leaf in $\mathrm{FF}+3 \mathrm{~A}$, $\mathrm{FF}+4 \mathrm{~A}, \mathrm{FF}+5 \mathrm{~A}$, and $\mathrm{FF}+8 \mathrm{~A}$. In all types of the AMALs and $A$. fistulosum, the numbers of expanded leaves decreased gradually from August to February (Fig. 3). In $\mathrm{FF}+2 \mathrm{~A}$ and $\mathrm{FF}+7 \mathrm{~A}$, the numbers of leaves were increased again from October to November. This phenomenon was

Table 2. Morphological data on leaves of alien monosomic addition lines

\begin{tabular}{|c|c|c|c|c|c|c|c|c|c|c|}
\hline \multicolumn{2}{|l|}{ Plant material } & \multirow{2}{*}{$\begin{array}{l}\text { No. of } \\
\text { plants } \\
\text { planted }\end{array}$} & \multirow{2}{*}{$\begin{array}{l}\text { Survival } \\
\text { rate }(\%)\end{array}$} & \multirow{2}{*}{$\begin{array}{l}\text { No. of } \\
\text { tillers }\end{array}$} & \multicolumn{3}{|c|}{ Leaf length $(\mathrm{cm})^{\mathrm{a}}$} & \multirow{2}{*}{$\begin{array}{c}\text { Leaf sheath } \\
\text { diameter }(\mathrm{cm})^{\mathrm{a}}\end{array}$} & \multicolumn{2}{|c|}{ Leaf color } \\
\hline $\begin{array}{l}\text { Extra } \\
\text { chromosome }\end{array}$ & $\begin{array}{l}\text { No. of } \\
\text { lines }\end{array}$ & & & & sheath & blade & total & & sheath $^{b}$ & blade $^{c}$ \\
\hline $1 \mathrm{~A}$ & 5 & 82 & 46.3 & $5.7 \pm 0.6$ & $10.9 \pm 0.3$ & $40.4 \pm 1.1$ & $51.3 \pm 1.4$ & $5.3 \pm 0.1$ & - & $3.4 \pm 0.8$ \\
\hline $2 \mathrm{~A}$ & 3 & 58 & 77.6 & $8.5 \pm 1.3$ & $9.2 \pm 0.5$ & $32.9 \pm 0.8$ & $42.1 \pm 1.1$ & $4.1 \pm 0.1$ & - & $1.0 \pm 0.0$ \\
\hline $3 \mathrm{~A}$ & 4 & 22 & 28.1 & $7.6 \pm 3.6$ & $11.0 \pm 0.4$ & $29.2 \pm 2.1$ & $40.2 \pm 2.3$ & $5.1 \pm 0.5$ & - & 2.0 \\
\hline $4 \mathrm{~A}$ & 8 & 108 & 87.0 & $4.7 \pm 0.4$ & $15.7 \pm 0.3$ & $55.8 \pm 0.8$ & $71.5 \pm 1.0$ & $6.1 \pm 0.1$ & - & $4.1 \pm 0.3$ \\
\hline $5 \mathrm{~A}$ & 3 & 55 & 80.0 & $8.3 \pm 0.8$ & $10.8 \pm 0.5$ & $36.5 \pm 1.0$ & $47.2 \pm 1.4$ & $5.1 \pm 0.1$ & + & $4.0 \pm 0.7$ \\
\hline $6 \mathrm{~A}$ & 2 & 48 & 77.1 & $5.3 \pm 0.6$ & $12.8 \pm 0.5$ & $49.2 \pm 1.4$ & $62.0 \pm 1.6$ & $4.9 \pm 0.1$ & - & 5.0 \\
\hline $7 \mathrm{~A}$ & 10 & 160 & 83.8 & $9.0 \pm 0.6$ & $12.4 \pm 0.3$ & $43.3 \pm 0.5$ & $55.7 \pm 0.7$ & $5.3 \pm 0.1$ & - & $1.1 \pm 0.1$ \\
\hline $8 \mathrm{~A}$ & 2 & 39 & 71.8 & $11.9 \pm 1.5$ & $14.3 \pm 0.5$ & $47.2 \pm 1.2$ & $61.5 \pm 1.5$ & $5.7 \pm 0.2$ & - & 4.0 \\
\hline A. fistulosum & 1 & 16 & 100.0 & $11.7 \pm 1.0$ & $18.3 \pm 0.8$ & $47.5 \pm 1.1$ & $65.9 \pm 1.6$ & $5.3 \pm 0.1$ & - & 3.0 \\
\hline
\end{tabular}

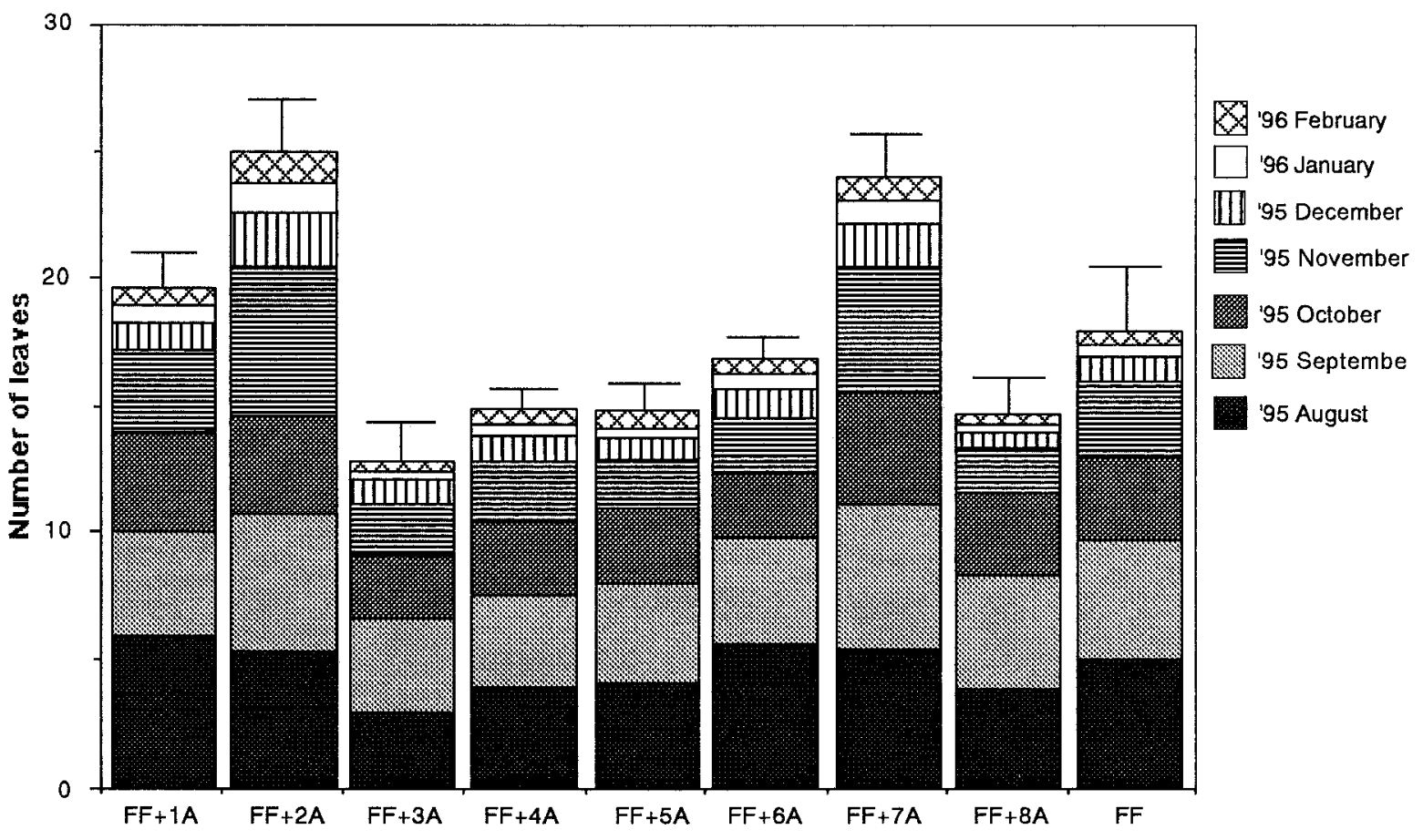

Fig. 3. Numbers of expanded leaves in alien monosomic addition lines $(\mathrm{FF}+1 \mathrm{~A}$ to $\mathrm{FF}+8 \mathrm{~A})$ and A. fistulosum (FF). 
related to the elongation of the axillary buds from late autumn to early winter. In $\mathrm{FF}+6 \mathrm{~A}$, arch-like expansion of leaves was observed (Fig. 4).

The longest length of flower stalk was observed in $\mathrm{FF}+8 \mathrm{~A}$ and the shortest one in FF+3A (Table 3). Large numbers of florets were shown in $\mathrm{FF}+4 \mathrm{~A}$ and $\mathrm{FF}+8 \mathrm{~A}$, and few ones in $\mathrm{FF}+3 \mathrm{~A}$ and $\mathrm{FF}+6 \mathrm{~A}$. There was no morphological difference on the floret characters except the size and color among eight types of the AMALs. Floret size of $\mathrm{FF}+4 \mathrm{~A}$ was much larger than those of other AMALs and A. fistulosum (Fig. 5). The anther color of $\mathrm{FF}+8 \mathrm{~A}$ showed more intense yellow than others, and those of $\mathrm{FF}+2 \mathrm{~A}, \mathrm{FF}+5 \mathrm{~A}$, and $\mathrm{FF}+6 \mathrm{~A}$ were lighter. The ovary color of $\mathrm{FF}+2 \mathrm{~A}$ showed the deepest green in all the plant materials. Considerable differences on the spathe shape were recognized among the AMALs and A. fistulosum; the spathes were spheroidal in $\mathrm{FF}+1 \mathrm{~A}$, small in $\mathrm{FF}+3 \mathrm{~A}$, acuminate in $\mathrm{FF}+4 \mathrm{~A}$, and pointed

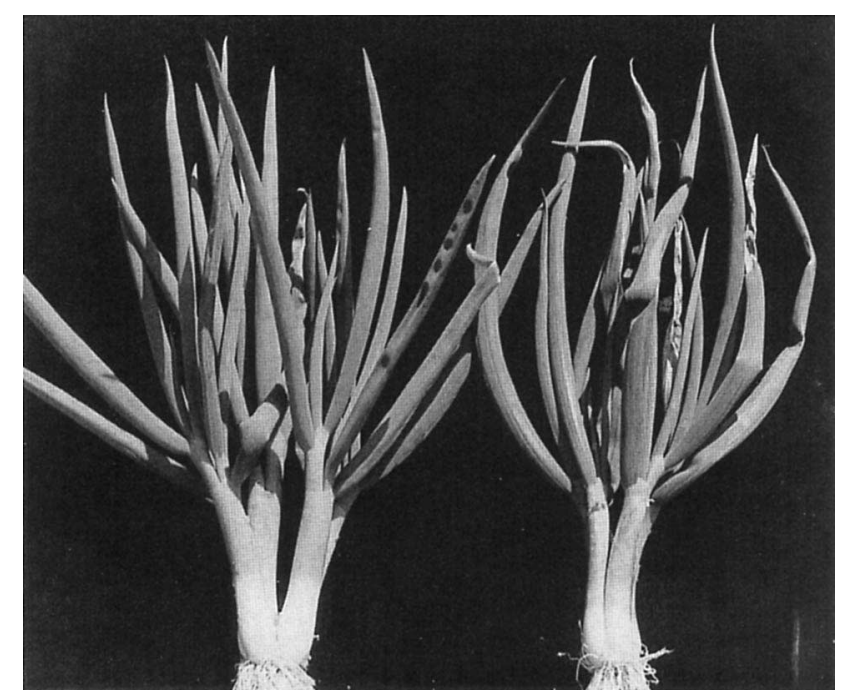

Fig. 4. Plants of A. fistulosum (left) and alien monosomic addition line $\mathrm{FF}+6 \mathrm{~A}$ (right). $\mathrm{FF}+6 \mathrm{~A}$ shows arch-like expansion of leaf. $\times c a .1 / 10$. in A. fistulosum (Fig. 6).

The morphological characteristics of the series of the AMALs are summarized in Table 4. This table eloquently tells that eight types of the AMALs have significant differences in morphological characteristics. It is clear that these characteristics are deeply concerned with alien genes on extra chromosomes from A. cepa Aggregatum group. It was difficult to examine the morphological characteristics of A. cepa Aggregatum group with the AMALs and A. fistulosum at the same time. In A. cepa Aggregatum group, a bulb formation and a subsequent dormancy was observed in summer season and continuous boltings were shown from winter to spring (data not shown). Therefore, the growth habits of this species were quite different from those of $A$. fistulosum. In general terms, all the AMALs examined in this study had growth habits similar to A. fistulosum rather than A. cepa Aggregatum group. It seems that the expres-

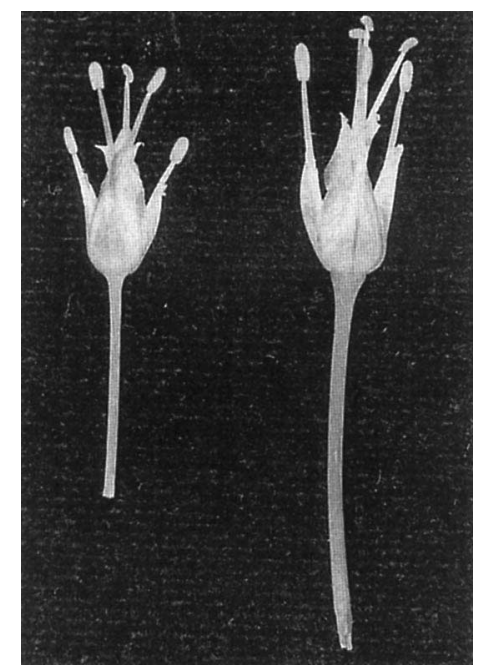

Fig. 5. Florets of A. fistulosum (left) and alien monosomic addition line $\mathrm{FF}+4 \mathrm{~A}$ (right). $\mathrm{FF}+4 \mathrm{~A}$ shows very large floret size. $\times c a .2$.

Table 3. Morphological data on flowers of alien monosomic addition lines

\begin{tabular}{|c|c|c|c|c|c|c|c|c|c|c|}
\hline \multicolumn{2}{|l|}{ Plant material } & \multirow{2}{*}{$\begin{array}{l}\text { Flower stalk } \\
\text { length }(\mathrm{cm})^{\mathrm{a}}\end{array}$} & \multirow{2}{*}{$\begin{array}{l}\text { No. of } \\
\text { florets }^{\text {a }}\end{array}$} & \multirow{2}{*}{$\begin{array}{c}\text { Pedicel } \\
\text { length }(\mathrm{mm})^{\mathrm{a}}\end{array}$} & \multicolumn{2}{|c|}{ Filament length $(\mathrm{mm})^{\mathrm{a}}$} & \multicolumn{2}{|c|}{ Anther size $(\mathrm{mm})^{\mathrm{a}}$} & \multirow{2}{*}{$\begin{array}{l}\text { Anther } \\
\text { color }^{b}\end{array}$} & \multirow{2}{*}{$\begin{array}{l}\text { Ovary } \\
\text { color }^{c}\end{array}$} \\
\hline $\begin{array}{l}\text { Extra } \\
\text { chromosome }\end{array}$ & $\begin{array}{l}\text { No. of } \\
\text { lines }\end{array}$ & & & & outer & inner & length & width & & \\
\hline $1 \mathrm{~A}$ & 5 & $53.3 \pm 1.1$ & $440 \pm 20$ & $11.4 \pm 0.5$ & $9.6 \pm 0.4$ & $8.3 \pm 0.3$ & $2.0 \pm 0.0$ & $1.0 \pm 0.0$ & $6.2 \pm 1.0$ & $3.6 \pm 0.8$ \\
\hline $2 \mathrm{~A}$ & 3 & $58.4 \pm 1.6$ & 425 & $7.7 \pm 0.5$ & $9.2 \pm 0.2$ & $8.7 \pm 0.3$ & $1.9 \pm 0.1$ & $1.0 \pm 0.0$ & $3.0 \pm 0.7$ & $6.0 \pm 0.0$ \\
\hline $3 \mathrm{~A}$ & 4 & $43.8 \pm 0.9$ & $317 \pm 36$ & $10.3 \pm 0.4$ & $10.5 \pm 0.1$ & $10.7 \pm 0.3$ & $1.8 \pm 0.1$ & $1.0 \pm 0.0$ & $5.5 \pm 0.8$ & $3.6 \pm 1.2$ \\
\hline $4 \mathrm{~A}$ & 8 & $69.3 \pm 0.8$ & $647 \pm 37$ & $16.0 \pm 0.9$ & $12.4 \pm 0.3$ & $11.6 \pm 0.4$ & $2.2 \pm 0.1$ & $1.1 \pm 0.1$ & $4.6 \pm 0.6$ & $5.4 \pm 0.4$ \\
\hline $5 \mathrm{~A}$ & 3 & $60.1 \pm 1.6$ & $386 \pm 36$ & $15.8 \pm 1.2$ & $10.0 \pm 0.3$ & $9.4 \pm 0.3$ & $1.9 \pm 0.1$ & $1.0 \pm 0.0$ & $3.3 \pm 0.4$ & $4.2 \pm 1.2$ \\
\hline $6 \mathrm{~A}$ & 2 & $69.1 \pm 2.5$ & 343 & $10.6 \pm 0.3$ & $10.9 \pm 0.4$ & $9.9 \pm 0.2$ & $2.0 \pm 0.0$ & $1.0 \pm 0.0$ & 3.3 & 1.5 \\
\hline $7 \mathrm{~A}$ & 10 & $59.7 \pm 0.7$ & $486 \pm 23$ & $14.1 \pm 0.5$ & $9.8 \pm 0.2$ & $9.4 \pm 0.2$ & $2.1 \pm 0.0$ & $1.1 \pm 0.0$ & $5.8 \pm 0.5$ & $3.1 \pm 0.4$ \\
\hline $8 \mathrm{~A}$ & 2 & $73.0 \pm 1.2$ & 554 & $10.9 \pm 0.3$ & $11.5 \pm 0.2$ & $11.1 \pm 0.3$ & $1.8 \pm 0.1$ & $1.0 \pm 0.0$ & 6.5 & 4.0 \\
\hline A. fistulosum & 1 & $61.8 \pm 2.9$ & 558 & $11.6 \pm 0.5$ & $10.1 \pm 0.9$ & $9.3 \pm 0.5$ & $2.0 \pm 0.0$ & $1.0 \pm 0.0$ & 5.0 & 4.0 \\
\hline
\end{tabular}

a Data are shown with mean $\pm \mathrm{SE}$. ${ }^{\mathrm{b}}$ Mean $\pm \mathrm{SE}$ of color scales from 1 (light yellow) to 7 (deep yellow). ${ }^{\mathrm{c}} \mathrm{Mean} \pm \mathrm{SE}$ of color scales from 1 (light green) to 5 (deep green). 

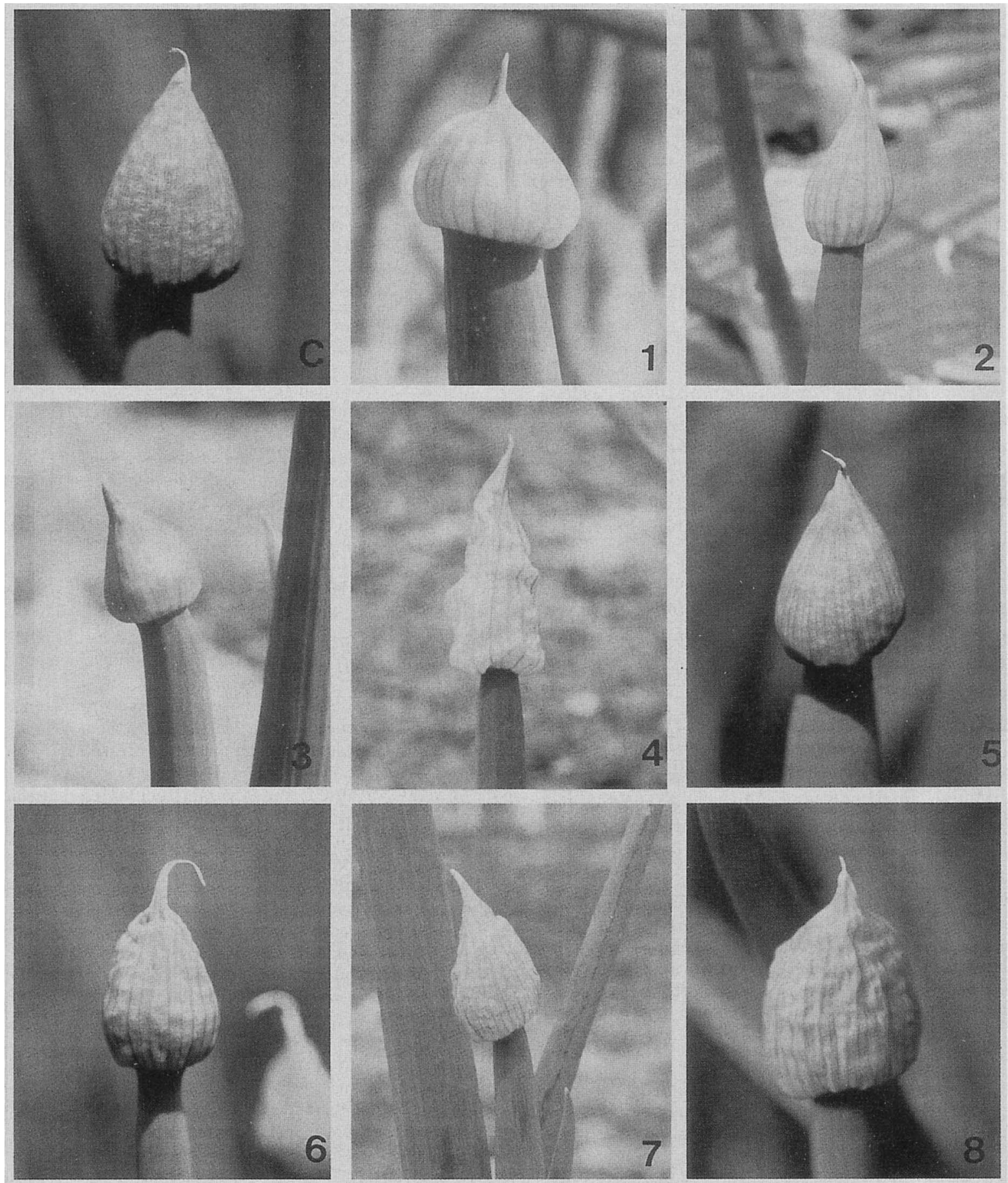

Fig. 6. Spathes of a series of alien monosomic addition lines (1-8) and A. fistulosum (C). Each arabic numeral (1-8) corresponds to the extra chromosomes $(1 \mathrm{~A}-8 \mathrm{~A})$ of the alien monosomic addition lines. FF+1A has a spheroidal spathe. FF+3A has a small spathe. FF+4A has an acuminate spathe. $\times c a .1$.

sion of the genes in A. fistulosum was partially modified by the alien genes.

In A. cepa, genetic analyses on some morphological characters had been carried out, and modes of inheritance of the characters were demonstrated (Dowker, 1990). A study on the glossy foliage character (due to absence of wax on the surface) showed that normal green foliage was dominant over glossy and that a pair of factors (G1/g1) was involved (Jones et al., 1944). In the present study, bloomless leaf blades were observed only in FF+2A. Since all the plants of $\mathrm{FF}+2 \mathrm{~A}$ examined showed this characteristic, it seems that the gene related to the character are located 
Table 4. Morphological characteristics of alien monosomic addition lines (AMALs)

\begin{tabular}{cl}
\hline \hline AMAL & \multicolumn{1}{c}{ Characteristic } \\
\hline FF+1A & $\begin{array}{l}\text { a little shorter leaf length, a little shorter flower stalk length, fast expansion of leaf, spheroidal spathe. } \\
\text { short leaf length, short flower stalk length, slender leaf blade, light green leaf blade, bloom-less leaf blade, light yellow } \\
\text { pollen, fast expansion of leaf, small floret, elongation of axillary bud from autumn to winter. } \\
\text { short leaf length, short flower stalk length, slow expansion of leaf, small spathe. } \\
\text { long leaf length, long flower stalk length, tough leaf blade, deep green leaf blade, few tillering, slow expansion of leaf, large } \\
\text { floret, acuminate spathe. }\end{array}$ \\
FF+4A & $\begin{array}{l}\text { a little shorter leaf length, a little shorter flower stalk length, slow expansion of leaf, reddish-eyellow leaf sheath. } \\
\text { a little slender leaf blade, deep green leaf blade, arch-like expansion of leaf. }\end{array}$ \\
FF+6A & $\begin{array}{l}\text { fast expansion of leaf, elongation of axillary bud from autumn to winter. } \\
\text { FF+7A }\end{array}$
\end{tabular}

on the extra chromosome $2 \mathrm{~A}$. Inheritance of bulb color in A. сера was reported by a few researchers (Clarke et al., 1944; Jones and Peterson, 1952; El-Shafie and Davis, 1967). Three color classes, white, yellow, and red, were examined and a series of complementary epistatic genes was shown to control color with a basic color factor (C) necessary for the development of red or yellow color and additional genes I, L, R, and G. In the present study, a reddish-yellow leaf sheath was observed only in FF+5A. Therefore, it is estimated that important genes for controlling the pigment production are located on the extra chromosome 5A.

The effects of extra chromosomes from A. cepa Aggregatum group on morphological characters in A. fistulosum were roughly grasped at the first time in Allium by the present study. Further studies on the chromosomal locations and localizations of the genes controlling the characters are necessary for gene manipulation in Allium.

The authors are grateful to T. Miyazaki of Saga University for his valuable suggestions and continuous encouragement. The research was supported in part by Grant-in-Aid for Research Fellow (M. S.) of the Japan Society for the Promotion of Science (No. 0058) from the Ministry of Education, Science, Sports, and Culture of Japan.

\section{REFERENCES}

Clarke, A. E., Jones, H. A., and Little, T. M. (1944) Inheritance of bulb color in the onion. Genetics 29, 569-575.

Dowker, B. D. (1990) Onion breeding. In: Onions and Allied Crops, Vol. 1 (eds.: H. D. Rabinowitch and J. L. Brewster), pp. 215232. CRC Press, Inc., Boca Raton, FL.

El-Shafie, M. W. and Davis, G. N. (1967) Inheritance of bulb color in the onion (Allium cepa L.). Hilgardia 38, 607-622.
Jena, K. K. and Khush, G. S. (1989) Monosomic alien addition lines of rice: production, morphology, cytology, and breeding behavior. Genome 32, 449-455.

Jones, H. A., Clarke, A. E., and Stevenson, F. J. (1944) Studies in the genetics of the onion (Allium cepa L.). Proc. Am. Soc. Hortic. Sci. 44, 479-484.

Jones, H. A. and Peterson, C. E. (1952) Complementary factors for light-red bulb color in onions. Proc. Am. Soc. Hortic. Sci. 59, 457.

Lange, W., Bock, T. S. M. D, Van Geyt, J. P. C., and Oléo M. (1988) Monosomic additions in beet (Beta vulgaris) carrying extra chromosomes of B. procumbens. 2. Effects of the alien chromosomes on in vivo and in vitro plant development. Theor. Appl. Genet. 76, 656-664.

Reamon-Ramos, S. M. and Wricke, G. (1992) A full set of monosomic addition lines in Beta vulgaris from Beta webbiana: morphology and isozyme markers. Theor. Appl. Genet. 84, 411-418.

Shigyo, M., Tashiro, Y., and Miyazaki, S. (1994) Chromosomal locations of glutamate oxaloacetate transaminase gene loci in Japanese bunching onion (Allium fistulosum L.) and shallot (A. сера L. Aggregatum group). Jpn. J. Genet. 69, 417-424.

Shigyo, M., Tashiro, Y., Isshiki, S., and Miyazaki, S. (1995a) Chromosomal locations of five isozyme gene loci (Lap-1, Got-1, 6Pgdh-2, Adh-1 and Gdh-1) in shallot (A. cepa L. Aggregatum group). Jpn. J. Genet. 70, 399-407.

Shigyo, M., Tashiro, Y., Isshiki, S., and Miyazaki, S. (1995b) Chromosomal locations of isocitrate dehydrogenase and phosphoglucoisomerase gene loci in shallot (A. cepa L. Aggregatum group). Jpn. J. Genet. 70, 627-632.

Shigyo, M., Tashiro, Y., Isshiki, S., and Miyazaki, S. (1996) Establishment of a series of alien monosomic addition lines of Japanese bunching onion (Allium fistulosum L.) with extra chromosomes from shallot (A. cepa L. Aggregatum group). Genes Genet. Syst. 71, 363-371.

Yasui, H. (1997) Cytogenetical studies on alien chromosome addition lines in rice (Oryza sativa L.), each carrying a single chromosome(s) of O. punctata Kotschy. Ph. D. Thesis, Kyushu Univ., Fukuoka, Japan. 